\title{
The milk fat globule membrane as an ingredient: why, how, when?
}

\author{
Rafael JiMÉNEZ-FLORES*, Guillaume BRISSON \\ Dairy Products Technology Center, California Polytechnic State University, \\ San Luis Obispo, CA 93407, USA
}

\begin{abstract}
This paper presents a personal view on the potential applications of the milk fat globule membrane as an ingredient in the processed foods area. Several factors are of importance for this dissertation: the biological origin of the membrane, the voluminous literature on its individual components and their relationship with health and wellness, the biological role of milk in nutrition to mammals and the innovation on scientific tools being applied in many fields of chemistry and biology. We hope to give a glimpse of the reasons on why it is a good idea to use more efficiently the components of the milk fat globule membrane. In addition we consider current advances in the fractionation of milk components to propose how this ingredient can be produced. However, we leave the timing question, when?, open for discussion in the different scientific and technological fields.
\end{abstract}

\section{milk fat globule membrane (MFGM) / isolation / analytical tools / biological activities}

\begin{abstract}
摘要 - 乳脂肪球膜在食品工业中的应用。本文基于个人的观点对乳脂肪球膜作为一种食品 成分在食品加工领域中的潜在用途进行了论述。作者从以下几个重要方面进行了论述, 如膜 的生物来源, 关于单一化合物的文献报道以及这些化合物与人类健康之间的关系, 乳对哺乳 动物在营养方面的生物学作用, 以及通过化学和生物技术手段对这些化合物的改性等。希望 通过本文的介绍能够对有效地使用乳脂肪球膜中的化合物给出一些有用的建议和理由。加 之, 考虑到目前对乳研究的热点主要是对乳成分的分离及其生产; 然而, 如何实现这一目标, 则给科技工作者们留下了一个深远的话题。

\section{乳脂肪球膜 (MFGM) / 分离 / 分析手段 / 生物活性}

Résumé - Application de la membrane du globule gras du lait comme ingrédient : perspectives actuelles et futures. Cet article présente nos vues personnelles sur les applications potentielles de la membrane du globule gras du lait comme ingrédient dans le domaine de la transformation alimentaire. Notre réflexion s'articule sur les éléments suivants : l'origine biologique de la membrane du globule gras, la vaste littérature couvrant ses divers composants et leur impact sur la santé et le bien-être, le rôle nutritionnel du lait chez les mammifères et le recours à des outils analytiques novateurs associés aux domaines de la chimie et de la biologie. Nous espérons que ce survol permettra de convaincre le lecteur de l'importance d'optimiser l'utilisation des divers composants de la membrane du globule gras du lait. Cet article propose également un aperçu des plus récents développements techniques qui permettront de fractionner et de produire commercialement ces composants. Nul doute que la réalisation de ces défis continuera de stimuler les milieux scientifiques et technologiques.

membrane du globule gras du lait / séparation / analyse / activité biologique

* Corresponding author (通讯作者): rjimenez@calpoly.edu 


\section{INTRODUCTION}

This paper presents some relevant information on the potential of the milk fat globule membrane (MFGM) as an ingredient in our food supply. In today's world where milk fat has an image problem due to the load of saturated fat and the role of triglycerides in the modern American diet, it is important to emphasize that there are very important components in milk that have not been fully considered. Those are the minor lipids, glycolipids and glycoproteins that compose the MFGM. Since the industrialization of butter, these components have taken a second seat to primary commodity ingredients such as skim milk powder and whey protein concentrates. The lipids contained in buttermilk powder are not used to their full potential in the processed foods industry. In foods, these lipids exhibit superior emulsifying properties, and help significantly in thickening formulations due to water distribution properties, and also aid where foaming is important such as in ice cream. However, the popular current view of buttermilk is of a milk-derived powder with an important liability; it goes rancid in about 6 months due to lipid oxidation.

This view overlooks the fact that buttermilk contains the MFGM components that in today's world can give the lipids of milk some better public relations image. The glycoproteins and lipids it contains may have been contributors to wellness in traditional diets even if we have not been fully aware of this. The fact that MFGM is rich in important minor lipids and glycoproteins found only in specific animal tissues (such as brain) which makes it valuable in our diets. Some of these lipids are sphingomyelin (SP), phosphatydylserine (PS) and phosphatidylcholine (PC), together considered milk-derived lecithin, and other minor lipids (such as gangliosides and cerebrosides); all are necessary in a healthy diet.
In this paper we will try to bring MFGM and its potential relevance in the context of a new challenge confronting the food scientist and technologist of today. Demand of consumers for better and healthier foods while at the same time maintaining safety, demands that the technologist of today recognize the natural biological role of the food components, isolate the important factors that impart the functional and nutritional benefit while at the same time considering the matrix of the food, and finally design a process that preserves the targeted biological and food function of the ingredient. True advancement in the development of the foods of the future may rest on the success that we have in addressing this challenge.

This idea is not new and has been presented before [61], where these ideas join the above mentioned challenge and suggests meeting it with the new tools available to scientist. Such tools include proteomics and genomics, where a large repository of information can be used to find out relationships among the components of a complex organism, and novel analytical methods that can be applied to complex systems. Milk is a good food in which to apply such concepts and in particular the MFGM. Its composition and its interactions with other components of milk and foods can be a starting point.

\section{ORIGIN AND FUNCTION OF THE MFGM}

The MFGM is a surface-active membrane surrounding each of the milk fat globules (MFG) allowing them to remain dispersed in milk. The MFG core is essentially composed of triacylglycerides (TG), while the MFGM envelope is a true polar lipids bilayer with proteins, enzymes, neutral lipids and other trace components [11]. The composition of the milk fat constituents and their distribution between the 
Table I. General composition of the milk lipids and their distribution between the milk fat globule (MFG) and the milk fat globule membrane (MFGM) (adapted from Walstra et al. [60], Jensen [27], Michalski and Januel [34]).

\begin{tabular}{lccc} 
& & \multicolumn{2}{c}{ Fraction content in } \\
\hline Lipid class & Total fat & MFG & MFGM \\
& & & \\
& $\left(\mathbf{g} \cdot \mathbf{k g}^{-1}\right)$ & $(\boldsymbol{\%})$ & $(\%)$ \\
\hline Neutral glycerides & & & \\
Triacylglycerol & $38.3-39.3$ & 100 & \\
Diacylglycerol & $0.11-0.90$ & $\approx 90$ & $\approx 10$ \\
Mono-acylglycerol & $0.01-0.17$ & Traces & Traces \\
Free fatty acids & $0.04-0.18$ & 60 & $\approx 10$ \\
Phospholipids & $0.08-0.44$ & - & 65 \\
Cerebroside & 0.4 & - & 70 \\
Gangliosides & 0.004 & - & $\approx 70$ \\
Sterols & & 80 & 10 \\
Cholesterol & $0.12-0.18$ & & \\
Cholesteryl ester & $\leqslant 0.008$ & & $\approx 5$ \\
Carotenoids + Vitamin A & 0.0008 & $\approx 95$ & \\
\hline
\end{tabular}

MFG core and the MFGM is given in Table I. The MFGM structure could be considered, to some extent, as the fingerprints of the milk fat biosynthesis in the mammary epithelial cells. Thus, a brief overview on the milk fat synthesis is essential to get a better understanding of the MFGM structure. However, due to the complexity of the MFG secretion process, some of the reports of the latest advances on the topic are strongly suggested to the reader $[11,24,29-31]$. To summarize, milk fat secretion starts in the epithelial cell's endoplasmic reticulum as micro lipid droplets (MLD). Upon their release into the cytoplasm, these MLD coalesce into larger droplets called the cytoplasmic lipid droplets (CLDs). While the CLDs migrate toward the apical pole of the epithelial cell's membrane, various components, such as phospholipids, glycosphingolipids, cholesterol and proteins, coat their surface. This interface is the inner layer of the MFGM. The peripheral layer of the MFGM is formed during the excretion of the CLDs out of the epithelial cells by a process generally referred as the milk fat globule "budding". The CLDs are gradually surrounded by the cell membrane before being expelled into the alveolar lumen. Upon closure of the cell membrane, some components of the cytoplasm could be entrenched between the inner and the peripheral membrane layer forming "crescents" on the globule surface (under the microscope, the cytoplasmic material resembles a moon crescent, Fig. 1). The MFGM peripheral membrane is a true polar lipids bilayer that includes an amalgam of glycoproteins, enzymes and phosphoproteins. To complete the picture, an electron dense layer is located at the inner face of the peripheral membrane. This layer is composed of proteins such as xanthine oxidase (XO), butyrophilin (BTN), and adipophilin (ADPH) among many others.

Because of its cellular membrane origin, the MFGM is the richest source of phospholipids, glycolipids, gangliosides, and glycoprotein in milk. The properties of the MFGM components have been recently 


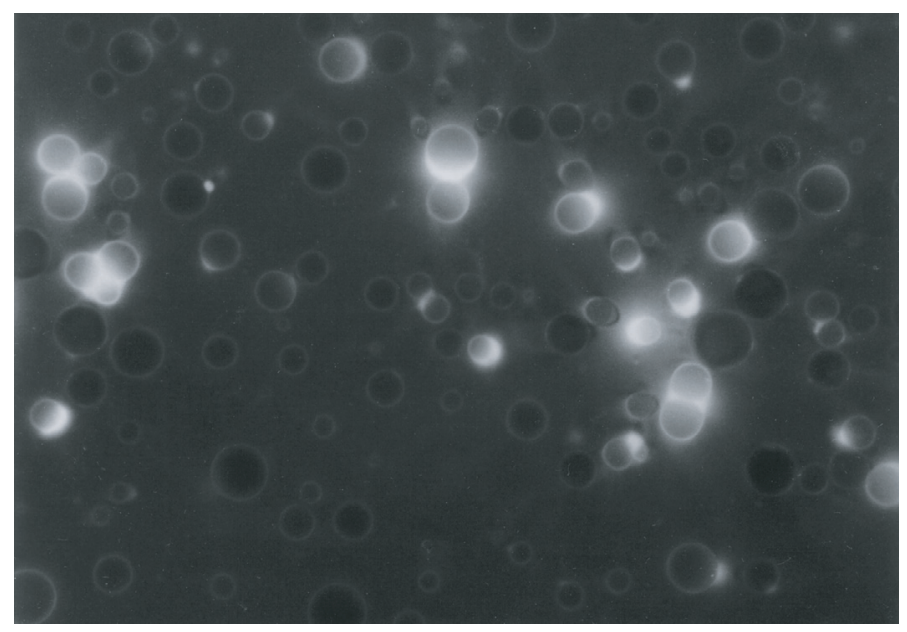

Figure 1. Milk fat globule crescents fluorescently stained with acrydine orange. (Picture from Huston and Patton [25], personal communication).

investigated and a number of health benefits have been reported (Tab. II). These MFGM biological activities have triggered thoughts of its potential as a nutraceutical in food applications [58]. However, this potential has yet to be fulfilled and some structural considerations of the MFGM in regards of the suggested health benefits need to be assessed.

\section{STRUCTURAL CONSIDERATIONS OF THE MFGM}

The surface of the MFGM, considering the above description of its origin, is anything but homogeneous. Perhaps a view on the comparison of the MFGM of different milks can give us better clues as to their biological roles. Based on some descriptive work [62] where a remarkable intraand site-specific variability of MFGM glycoproteins was detected, a suggestion was made that they play a role in the intestine of the new born. Observing the interactions of the globules in Figure 1 [25], it is important to notice that the globules are interacting among themselves through sections of the membrane that is presumably in its native state. That is, since the presence of the crescents indicate that the cytoplasm between the membrane and the triglyceride globule forces the membrane has to be in its bilayer form. This observation begs the question, would the interaction among membranes of the intestine and the MFGM follow such a specific interaction? If so we can imagine an interaction between membranes designed for nutrition delivery.

Biologist and chemist may give us some information on the structure and the binding function of the MFGM, and hopefully in a near future we will find out more on the role of this component in nutrition. However, in the present paper, we shall examine where this membrane resides, and what efforts are being made to enrich this component and make it into a dairy ingredient we could use in the food industry.

\section{MFGM ISOLATION}

The most important source of MFGM material is buttermilk, the by-product of butter making. While churning cream, the 
Table II. Reported health benefits claims of different MFGM components (adapted from Riccio [44], Spitsberg [58], Pan et al. [42], Fong et al. [17], Michalski and Januel [34]).

\begin{tabular}{|c|c|c|}
\hline Proteins & $\begin{array}{l}\text { Molecular } \\
\text { mass } \\
\left(\mathrm{kg} \cdot \mathbf{m o l}^{-1}\right)\end{array}$ & Reported health benefits \\
\hline Mucin 1 (MUC1) & 160 & Antiviral action/Anti Rotavirus \\
\hline Mucin 15 (MUC15 or PAS III) & $94-100$ & Antiviral action \\
\hline Butyrophilin (BTN) & 66 & Suppression of multiple sclerosis \\
\hline Xanthine oxidase (XO) & 155 & Bactericidal agent \\
\hline $\begin{array}{l}\text { Cluster of differentiation } \\
\text { (CD36 or PAS IV)) }\end{array}$ & 78 & $\begin{array}{l}\text { Glycoproteins that act as receptors due to high sugar } \\
\text { content }\end{array}$ \\
\hline $\begin{array}{l}\text { Fatty acid binding protein } \\
\text { (FABP) }\end{array}$ & 15 & $\begin{array}{l}\text { Cell growth inhibitor } \\
\text { Anti-cancer factor }\end{array}$ \\
\hline BRCA1 and BRCA2 & 210 & Inhibition of breast cancer \\
\hline Lactadherin (PAS 6/7) & $43-59$ & $\begin{array}{l}\text { Role in epithelialization, cell polarization, cell } \\
\text { movement and rearrangement, neurite outgrowth, } \\
\text { synaptic activity in the central nervous system, } \\
\text { protection against viral infection in the gut }\end{array}$ \\
\hline Adipophilin (ADPH) & 52 & Milk synthesis \\
\hline \multicolumn{3}{|l|}{ Other components } \\
\hline$\beta$-Glucoronidase inhibitor & & Inhibition of colon cancer \\
\hline Helicobacter pylori inhibitor & & Prevention of gastric diseases \\
\hline $\begin{array}{l}\text { Cholesterolemia-lowering } \\
\text { factor }\end{array}$ & & Anti-cholesterol activity \\
\hline Vitamin $\mathrm{E}$ and carotenoids & & Anti-oxydants \\
\hline Phospholipids & & Inhibition of colon cancer, anti-cholesterol activity, \\
\hline Shingomyelin & & Suppression of gastrointestinal pathogens \\
\hline & & Anti-Alzeimer, anti-depressant, anti-stress \\
\hline Phosphoproteins & & Source of organic phosphorus and Ca-phosphate \\
\hline
\end{tabular}

membrane of the milk fat globule is disrupted and MFGM fragments are released in the buttermilk accompanied with the rest of the water-soluble fraction, such as the proteins, lactose and minerals. To give an idea of the importance of this byproduct, from the 610 million $\mathrm{kg}$ of butter produced annually in the US, 35.4 million $\mathrm{kg}$ of buttermilk are condensed or evaporated [1]. These buttermilk ingredients have been commercially used essentially for their good emulsifying properties in a wide range of products $[8,9,28,57]$. However, the potential of the MFGM components in regard to their health benefits is not fully realized or used in these commodity products. Moreover, the numerous processing steps sustained by the buttermilk could impair the MFGM nutritional and biological value. Thus, the challenge that faces food scientists is to develop proper techniques that allow MFGM isolation or enrichment while maintaining its biological value.

So far, the most feasible approach investigated to fractionate or concentrate MFGM from buttermilk has been the use of tangential cross-flow membrane filtration. Microfiltration (MF) is well suited for the fractionation of buttermilk since its pore size range corresponds approximately to the MFGM fragments size $(\geqslant 0.1 \mu \mathrm{m}[38])$. Many efforts have been directed in the improvement of the 
retention of MFGM fragments during the MF of buttermilk by adjusting the process parameters such as temperature, membrane pore size, and the addition of a diafiltration step $[5,37,59]$. However, those who have been working with the direct MF of buttermilk have face a similar problem, namely the presence of caseins. In fact, in their micellar forms, the caseins are comparable in size with the MFGM fragments and conjointly retained during MF. Different pretreatments have been applied to the buttermilk to overcome this problem. For example, Sachdeva and Buchheim [50] used acid or rennet coagulation to remove the casein prior to filtration. Other authors have investigated the ability of different techniques to dissociate the casein micelles in order to improve their permeation during MF by either enzyme cleavage [45] or sodium citrate [10]. Morin et al. [40] have tested a wash cream process [7] to produce a casein depleted buttermilk to improve the MF separation performances. The use of different MFGM sources has also been examined. Rombaut et al. [46] have evaluated the feasibility of MF of buttermilk sera, a MFGM rich by-product of the anhydrous milk fat production, after casein micelles destabilization. The same group of authors also have adapted the thermolcalcic aggregation process developed for the delipidation of cheese or acid whey $[15,16]$ for the precipitation of MFGM fragments in acid buttermilk cheese whey [48]. They also investigated the recovery of the precipitated MFGM fragments by means of MF [47]. The use of whey buttermilk, the by-product from the churning of the casein depleted whey cream, has also been investigated [39]. We also developed new approaches to further separate buttermilk components by using biosilicates to remove proteins and non-polar lipids from buttermilk [19]. Furthermore, a technique using supercritical $\mathrm{CO}_{2}$ extraction on $\mathrm{MF}$ buttermilk powder has shown its ability to separate the MFGM polar lipids from the non-polar lipids [5]. Another research group designed a MF process of whole milk that allowed the selective separation of the MFG in their native forms according to their diameters $[20,21,35]$. This process has been showed to increase the MFGM content in dairy products by collecting selectively the smaller globules richer in MFGM [20,35].

As seen above, several research groups are actively working on the improvement of the separation process of MFGM. These recent advancements open the route for new applications of the MFGM materials. However, there is an increasing need for more refined techniques to further separate the different MFGM proteins or lipids. This will allow the realization of the individual properties of the MFGM components to respond to the growing need in new ingredients for very specific application.

\section{MFGM AND LACTIC ACID BACTERIA BINDING}

In this and the following sections we would like to propose a view on where the potential applications of the MFGM properties and biological activities are most likely to occur given some of the advances in the scientific and technological fields applied to food. Figure 2 represents a good graphic example of lactic acid bacteria binding to milk fat globules.

There are many similarities as to the components found on the MFGM and the intestinal cells. Carbohydrate chains, proteins, glycoproteins (e.g. Mucins), enzymes and phospholipids are present in both systems yet little has been researched as to what of these components plays a role in probiotics' success in dairy. We advance that in order to understand how probiotic bacteria transfer from the dairy product to the intestinal lining, the manner and mechanisms in which bacteria bind 
to different substrates must be understood. First we can consider the lactic acid bacteria (LAB). The main region they present to bind to surfaces is their calyx, of which two components are of great importance, exopolysaccharides, and surface proteins that for simplicity we will equate to the S-layer proteins, located at the surface of the bacterial cell. The bacterial cell surface carbohydrate binding proteins and the mechanism in which bacteria bind with the S-layer could be equivalent with the interaction between polysaccharides and lectins $[51,52]$. Also it could be suggested that the carbohydrates provide some localized protection against proteases through steric hindrance or by creating a sheltered microenvironment [14]. The amount of Slayer protein present varies between $\mathrm{Lac}$ tobacillus strains but when present is the most dominant cellular protein [54]. Researchers have found that in some Lactobacillus strains, the S-layer is responsible for the cells ability to adhere to a substance for upon removal of the S-layer, the binding ability of the bacterium is greatly compromised [18, 49, 56].

On the other hand, considering the gastrointestinal tract there are three types of membrane-linked glycoconjugates that are thought to play key roles in the binding ability of probiotics: glycoproteins, proteoglycans and glycolipids. Bacterial adhesion is initially based on nonspecific physical interactions between two surfaces, which then enable specific interactions between adhesions (usually proteins) and complementary receptors [32]. Glycoproteins have been localized to a variety of extracellular matrices. They are large, complex, multidomain molecules with numerous biological activities, one of the most important of which involves their adherence to a variety of cell types through cell surface membrane receptors.

Given this complexity, it is important to study the factors that are important for the interaction between $\mathrm{LAB}$, intestine and
MFGM. To this effect our group has been studying these interactions. Many studies have focused on the protein binding properties while the binding to lipids has been poorly studied. We focused on developing an assay that gives a quantitative measurement of lactic acid bacteria's affinity to bind to various lipids found in dairy foods [13]. We found two types of lipid binding: non-specific binding to triglycerides (non-polar lipids), in which the lipid concentration was the significant variable, and strain specific binding to phospholipids (polar lipids), where regardless of composition, each strain showed specific binding affinity. More importantly, these results show the specificity of binding as the direct result of the degree of processing of the dairy product. Those powders with lower triglycerides or undergoing supercritical fluid extraction showed an increase in binding to phospholipids. These results will help in the design and formulation of dairy foods containing probiotic strains thus optimizing the bacteria's beneficial effects on health [13].

\section{ANTIVIRAL PROPERTIES OF THE MFGM}

Here is another example of an area where MFGM will very likely have a contribution in the near future. There is evidence today that the protection of milk to viral infections is through MFGM components. However, the exact mechanism seems to be complex and not due to a single component. Pan et al. [42] have published an extensive review on potential mechanism of lactoferrin as a powerful inhibitor of viral infectivity. Most of the research in this area has been made in vitro, and more evidence is needed for measuring this activity in vivo. There have been also many studies in which immunoglobulin in milk (natural and induced) have been tested for antiviral activity [2, 6, 43]. 


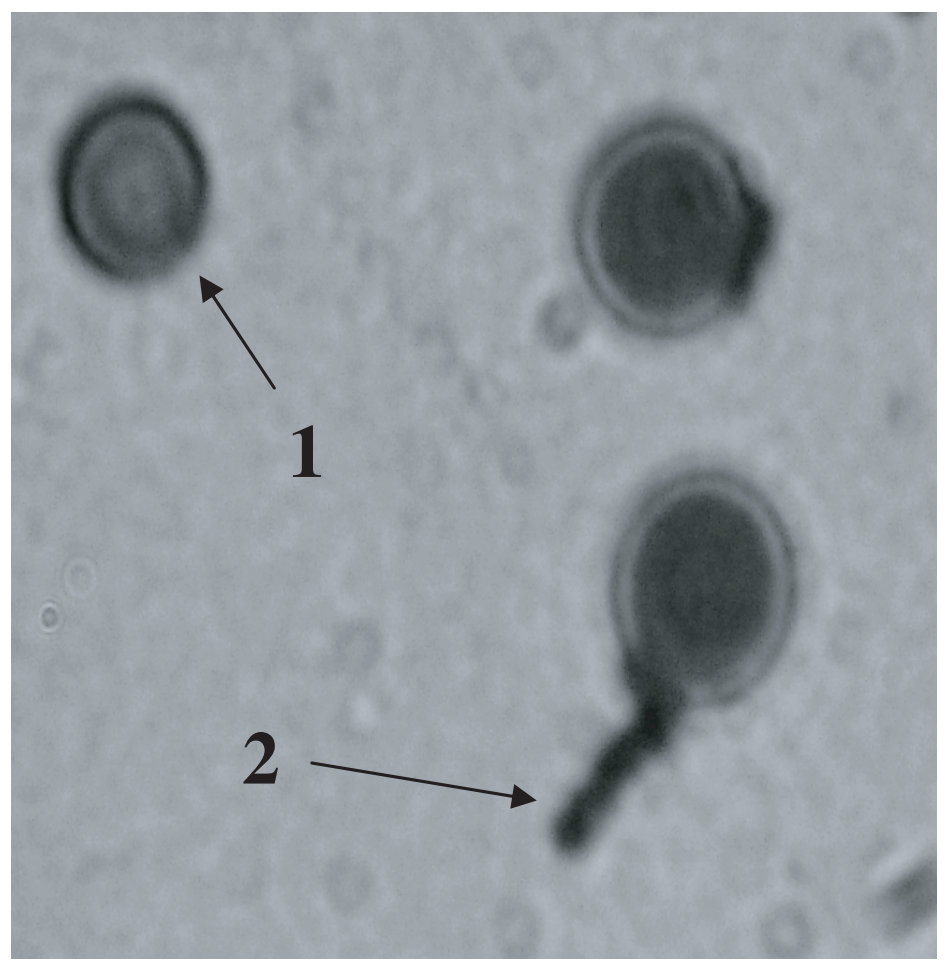

Figure 2. Microscope image of milk fat and lactic acid bacteria at $100 \times$ oil immersion with a depression slide. 1. Fat droplet and 2. lactic acid bacteria. (Picture from Elizondo-Bachiero [12]).

Asensi et al. [2] analyzed anti-rotavirus antibodies in human milk in order to determine their isotypes and neutralizing activity on rotavirus strains representing different viral serotypes. Interestingly, they concluded that anti-rotavirus antibodies are only partly responsible for the neutralizing activity detected in milk and serum [2]. Their result suggests that other components possessing suppressive activity against rotavirus must also be present. MFGM proteins are also well studied and in particular lactadherin has been found recently as a main component in the antirotaviral activity $[6,33]$. We further speculate, that not only the individual proteins and carbohydrates are players in this protective action against viral infections, but due to some of the similar results of
LAB binding to lipids, it seems logical to us to add the important role that lipids in the membranes play in the presentation of other biologically active membrane proteins to the "milieu" in which viral interactions take place; whether it is in the food or the intestine.

\section{NEW TOOLS TO MONITOR BIOLOGICAL ACTIVITY OF MFGM IN FOODS}

\subsection{Atomic force microscopy (AFM)}

AFM is the ideal technique to provide a means of visualizing, mapping and measuring monolayer domain formation, 


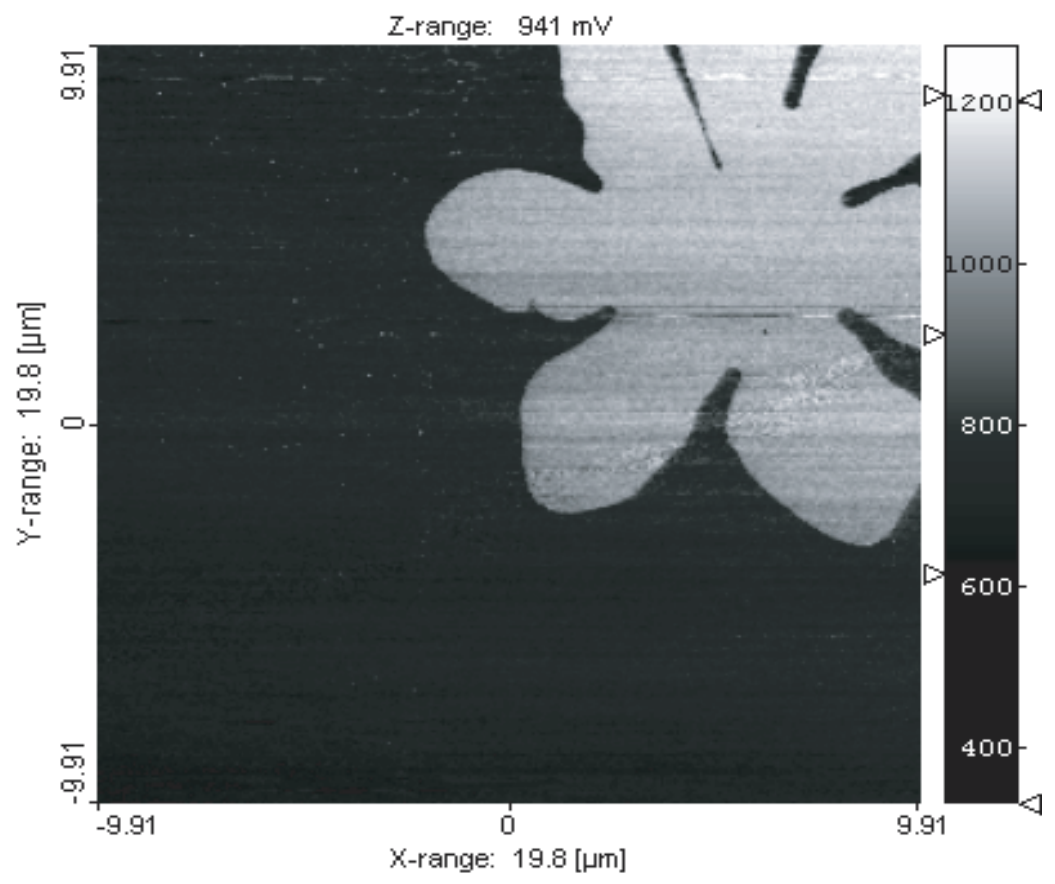

Figure 3. AFM phase image of a monolayer film prepared by depositing the MFGM components isolated from buttermilk powder using solid phase extraction (SPE) onto a mica surface at a film pressure of $40 \mathrm{mN} \cdot \mathrm{m}^{-1}$ and a temperature of $15^{\circ} \mathrm{C}$.

binding events, and other membranemembrane interactions. Evidence is growing that biological membranes contain lipid microdomains or "rafts" that may be involved in processes such as cellular signaling and protein trafficking [22,36,41,53,55,63]. An AFM operates by measuring attractive or repulsive forces between a tip and the sample [23]. In its repulsive "contact" mode, the instrument lightly touches a tip at the end of a leaf spring or "cantilever" to the sample. A laser beam is reflected from the back of the cantilever and detected by a split photodiode. As the tip raster scans over the sample, the vertical deflection of the cantilever, and thus the repulsive force, is measured by the change in direction of the reflected laser beam. In "constant force" mode, the signal from the photodiode is used to adjust the height of the cantilever, allowing the AFM tip to move over the surface while applying a constant force. Thus, in contact mode the AFM can be used to produce a height or topography image of the surface as well as measure forces.

Of special interest is the observation by Saslowsky and coworkers [53] that rafts formed in bilayers composed of dioleoylphosphatidylcholine and sphingomyelin are detectable as raised features by AFM. These authors were able to compare the extents of protrusion of the rafts in monolayers and bilayers to show that the raft is continuous across both layers of the bilayer. These studies demonstrate that AFM can be used to distinguish between different species on a membrane surface. In an applied experiment using milk 
lipids isolated from buttermilk, we have confirmed that domains can be detected even in monolayers, using AFM (Fig. 3). In Figure 3, we clearly see a different domain or "raft" formed on a Langmuir trough, in a film at a pressure of $40 \mathrm{mN} \cdot \mathrm{m}^{-1}$ and at a temperature of $15{ }^{\circ} \mathrm{C}$. We therefore think that the use of AFM as a powerful tool for the study of raft structure and properties.

\subsection{Laser tweezers in measuring properties of the MFGM}

Laser tweezers, sometimes called optical tweezers, is a technique built upon the principle that small particles/objects can be trapped in the waist of a strongly focused laser beam. The optical trap results from the fact that the objects that are trapped in the focus of the laser beam experience a restoring force if they try to leave the high intensity volume. The technique has its routs in the early seventies in the work by Ashkin [3] concerning trapping of micrometer-sized objects using two focused counter propagation laser beams. It took however until the mid-eighties before the optical tweezers based on one focused laser beam was realized [4]. Since then the optical tweezers technique has found its application in a number of fields, across all sciences. The optical tweezers system has been used for direct manipulation of a variety of micrometer-sized objects and for force measurement in the $\mathrm{pN}$ region.

The radiation pressure from a focused laser beam is able to trap small particles. In the biological sciences, these instruments have been used to apply forces in the $\mathrm{pN}$-range and to measure displacements in the $\mathrm{nm}$ range of objects ranging in size from $10 \mathrm{~nm}$ to over $100 \mu \mathrm{m}$. A laser beam is focused by a high-quality microscope objective to a spot in the specimen plane. This spot creates an "optical trap" which is able to hold a small particle at its center. The forces felt by this particle consist of the light scattering and gradient forces due to the interaction of the particle with the light (Fig. 4A).

Most frequently, optical tweezers are built by modifying a standard optical microscope. These instruments have evolved from simple tools to manipulate micron-sized objects to sophisticated devices under computer-control that can measure displacements and forces with high precision and accuracy. In our research group we have started a program using laser tweezers to measure objectively binding forces between bacteria and MFGM. This is best explained graphically in Figure 4B [26]. Objective measurements of the forces involved in binding through membrane-to-membrane interactions are of central importance for studies on the role of each of the MFGM components. Using this approach is easy to imagine a systematic examination of the role in interactions of the different components, proteins, glycoproteins and lipids among themselves and with their surroundings. The versatility of the technique allows for interrogation of interactions with bacteria or intestinal components under a variety of conditions. Furthermore, we hope to be able to use this procedure to elucidate the necessary combination of components involved in the efficient binding and related biological action of the MFGM, and that way generate better nutrition delivery systems.

\section{CONCLUDING REMARKS}

The challenge for the food technologist and scientist of the future will focus on the new demands on our foods. They will continue to be the source of nutrition but also of wellness, fitted to the individual life style and all of this delivered with outmost safety. To meet this challenge new tools are being used to generate data on our food components and their interactions. Ideally, 
$4 \mathrm{~A}$

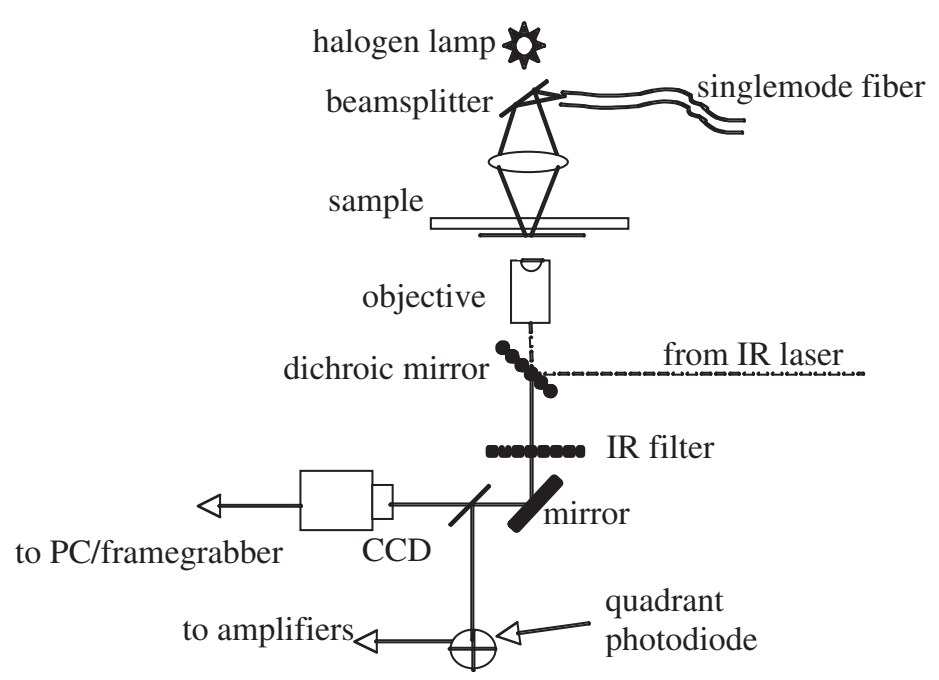

\section{B}

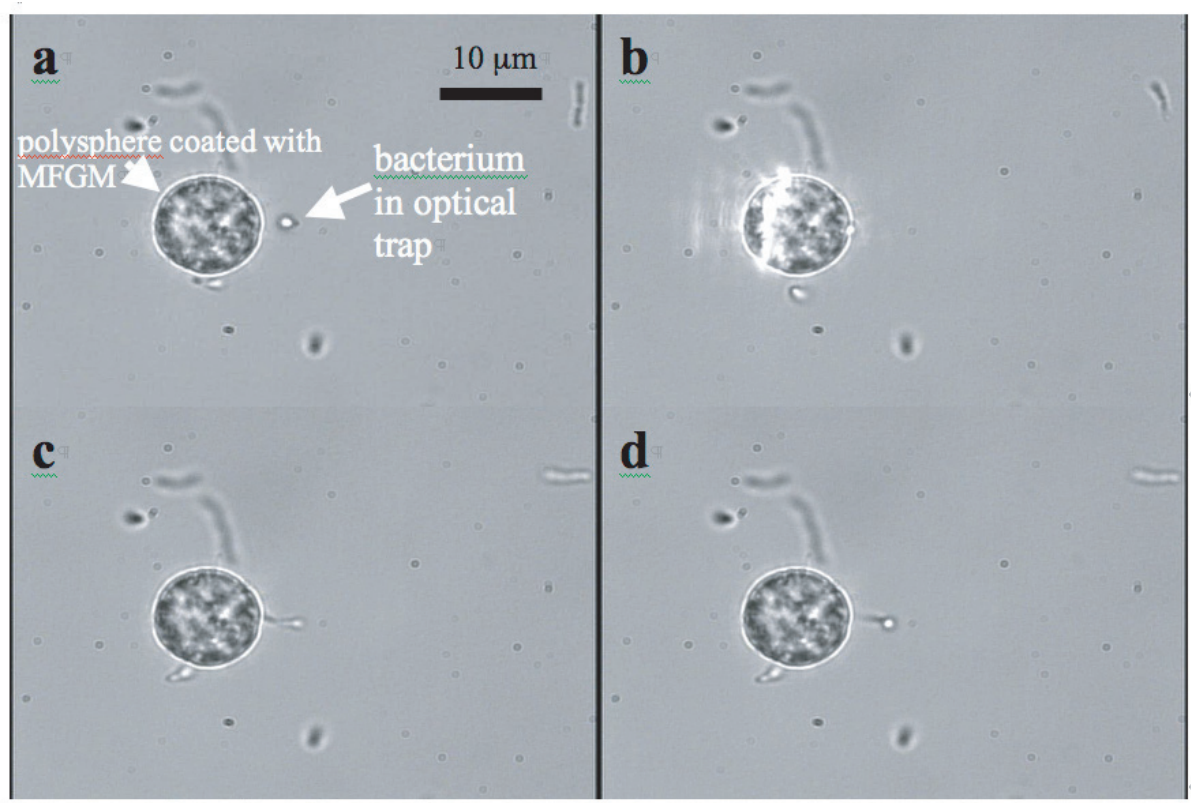

Figure 4. (A) Schematic of optical tweezers system. (B) Frames from a binding experiment using Laser tweezers. (a) Shows the MFGM coated sphere and the bacterium in the trap. The bacteria, which are long, tend to point straight up in the traps when unattached and appear circular. (b) Shows the bacterium just as we push it against the sphere. (c) Shows the bacterium being pulled with one end of it attached to the sphere. In (d) the bacterium has just detached. 
the application of our knowledge will be correlated to the complexity of the systems we can handle scientifically. We think that the MFGM is a good model in which to start testing these new concepts. This paper is a personal attempt to exemplify the information available for innovation in the area of dairy ingredients.

Acknowledgements: The authors want to acknowledge the help and contributions of Mrs D. Bachiero, Dr. D. Gragson, Dr. C. Iniguez, Dr. J. Sharpe, and the valuable help of Mrs M.P. Fortier for her help with French. The authors also want to acknowledge the support for our work by the California Dairy Research Foundation, Dairy Management Inc., and the CSU-Agricultural Research Initiative.

\section{REFERENCES}

[1] Anonymous, Dairy facts, International Dairy Foods Association, Washington DC, USA, 2006.

[2] Asensi M.T., Martinez-Costa C., Buesa J., Anti-rotavirus antibodies in human milk: Quantification and neutralizing activity, J. Pediatr. Gastroenterol. Nutr. 42 (2006) 560567.

[3] Ashkin A., Acceleration and trapping of particles by radiation pressure, Phys. Rev. Lett. 24 (1970) 156-159.

[4] Ashkin A., Dziedzic J.M., Bjorkholm J.E., Chu S., Observation of a single beam gradient force optical trap for dielectric particles, Optics Lett. 11 (1986) 288-290.

[5] Astaire J.C., Ward R., German J.B., JiménezFlores R., Concentration of polar MFGM lipids from buttermilk by microfiltration and supercritical fluid extraction, J. Dairy Sci. 86 (2003) 2297-2307.

[6] Bojsen A., Buesa J., Montava R., Kvistgaard A.S., Kongsbak M.B., Petersen T.E., Heegaard C.W., Rasmussen J.T., Inhibitory activities of bovine macromolecular whey proteins on rotavirus infections in vitro and in vivo, J. Dairy Sci. 90 (2007) 66-74.

[7] Britten M., Lamothe S., Robitaille G., Effect of cream treatment on phospholipids and protein recovery in butter making process, Int. J. Food Sci. Technol. (doi:10.1111/j.1362-2621.2007.01501.x)
[8] Corredig M., Dalgleish D.G., Isolates from industrial buttermilk: Emulsifying properties of materials derived from the milk fat globule membrane, J. Agric. Food Chem. 45 (1997) 4595-4600.

[9] Corredig M., Dalgleish D.G., Characterization of the interface of an oil-in-water emulsion stabilized by milk fat globule membrane material, J. Dairy Res. 65 (1998) 465-477.

[10] Corredig M., Roesch R.R., Dalgleish D.G., Production of a novel ingredient from buttermilk, J. Dairy Sci. 86 (2003) 2744-2750.

[11] Danthine S., Blecker C., Paquot M., Innocente N., Deroanne C., Progress in milk fat globule membrane research: A review, Lait 80 (2000) 209-222.

[12] Elizondo-Bachiero D.T., Interaction of probiotic bacteria and various components found in dairy products, Ms.D. thesis, California Polytechnic State University, San Luis Obispo, 2006, pp. 88.

[13] Elizondo-Bachiero D.T., Uson III I., Jiménez-Flores R., Lipid binding characterization of lactic acid bacteria in dairy products, in: Proceedings of the annual American Society for Microbiology, Toronto, Canada, 2007.

[14] Engelhardt H., Peters J., Structural research on surface layers: A focus on stability, surface layer homology domains, and surface layer-cell wall interactions, J. Struct. Biol. 124 (1998) 276-302.

[15] Fauquant J., Pierre A., Brulé G., Clarification du lactosérum acide de caséinerie, Tech. Lait. 1003 (1985) 37-41.

[16] Fauquant J., Vieco E., Brulé G., Maubois J.-L., Clarification of sweet cheese whey by thermocalcic aggregation of residual fat, Lait 65 (1985) 1-20.

[17] Fong B.Y., Norris C.S., Macgibbon A.K.H., Protein and lipid composition of bovine milk-fat-globule membrane, Int. Dairy J. 17 (2007) 275-288.

[18] Frece J., Kos B., Svetec I.K., Zgaga Z., Mrsa V., Suskovic J., Importance of S-layer proteins in probiotic activity of Lactobacillus acidophilus M92, J. Appl. Microbiol. 98 (2005) 285-292.

[19] Fryksdale B.G., Jiménez-Flores R. Modification of buttermilk functionality with biosilicate adsorption process, in: Proceedings of the IFT Annual Meeting, June 23-27, New Orleans, LA, USA, 2001, p. 209.

[20] Goudédranche H., Fauquant J., Maubois J.L., Fractionation of globular milk fat by 
membrane microfiltration, Lait 80 (2000) 93-98.

[21] Goudédranche H., Maubois J.-L., Fauquant J., Produits, en particulier laitiers, comprenant des fractions sélectionnées de globules gras, obtention et applications, Fr. Patent $2776208,1998$.

[22] Grauby-Heywang C., Turlet J.-M., Behavior of GM3 ganglioside in lipid monolayers mimicking rafts or fluid phase in membranes, Chem. Phys. Lipids 139 (2006) 6876.

[23] Gunning A.P., Wilde P.J., Clark D.C., Morris V.J., Parker M.L., Gunning P.A., Atomic force microscopy of interfacial protein films, J. Colloid Interface Sci. 183 (1996) 600-602.

[24] Heid H.W., Keenan T.W., Intracellular origin and secretion of milk fat globules, Eur. J. Cell Biol. 84 (2005) 245-258.

[25] Huston G.E., Patton S., Factors related to the formation of cytoplasmic crescents on milk fat globules, J. Dairy Sci. 73 (1990) 20612066.

[26] Iñiguez-Palomares C., Identificación de interacciones tipo adhesina-carbohidrato en la adherencia de Lactobacillus probióticos a la mucosa intestinal de lechones, Ph.D. thesis, CIAD Unidad Hermosillo, Sonora, Mexico, 2007.

[27] Jensen R.G., The composition of bovine milk lipids: January 1995 to December 2000, J. Dairy Sci. 85 (2002) 295-350.

[28] Kanno C., Shimomura Y., Takano E., Physicochemical properties of milk-fat emulsions stabilized with bovine-milk fat globule-membrane, J. Food Sci. 56 (1991) 1219-1223.

[29] Keenan T.W., Milk lipid globules and their surrounding membrane: A brief history and perspectives for future research, J. Mammary Gland Biol. Neoplasia 6 (2001) 365-371.

[30] Keenan T.W., Assembly and secretion of the lipid globules of milk, in: Newberg D.S. (Ed.), Bioactive components of human milk, Kluwer Academic/Plenum Publisher, New York, USA, 2001, pp. 125-136.

[31] Keenan T.W., Dylewski D.P., Intracellular origin of milk lipid globules and the nature and structure of the milk lipid globule membrane, in: Fox P.F. (Ed.), Advanced dairy chemistry, Volume 2: Lipids, Chapman \& Hall, New York, USA, 1995, pp. 89-130.

[32] Kirjavainena P.V., Ouwehand A.C., Isolauri E., Salminen S.J., The ability of probiotic bacteria to bind to human intestinal mucus, FEMS Microbiol. Lett. 167 (1998) 185-189.
[33] Kvistgaard A.S., Pallesen L.T., Arias C.F., Lopez S., Petersen T.E., Heegaard C.W., Rasmussen J.T., Inhibitory effects of human and bovine milk constituents on rotavirus infections, J. Dairy Sci. 87 (2004) 4088-4096.

[34] Michalski M.-C., Januel C., Does homogenization affect the human health properties of cow's milk? Trends Food Sci. Technol. 17 (2006) 423-437.

[35] Michalski M.C., Leconte N., BriardBion V., Fauquant J., Maubois J.-L., Goudédranche H., Microfiltration of raw whole milk to select fractions with different fat globule size distributions: Process optimization and analysis, J. Dairy Sci. 89 (2006) 3778-3790.

[36] Miyaji M., Jin Z.X., Yamaoka S., Amakawa R., Fukuhara S., Sato S.B., Kobayashi T., Domae N., Mimori T., Bloom E.T., Okazaki T., Umehara H., Role of membrane sphingomyelin and ceramide in platform formation for Fas-mediated apoptosis, J. Exp. Med. 202 (2005) 249-259.

[37] Morin P., Jiménez-Flores R., Pouliot Y., Effect of temperature and pore size on the fractionation of fresh and reconstituted buttermilk by microfiltration, J. Dairy Sci. 87 (2004) 267-273.

[38] Morin P., Jiménez-Flores R., Pouliot Y., Effect of processing on the composition and microstructure of buttermilk and its milk fat globule membranes, Int. Dairy J. 17 (2007) 1179-1187.

[39] Morin P., Pouliot Y., Jiménez-Flores R., A comparative study of the fractionation of regular buttermilk and whey buttermilk by microfiltration, J. Food Eng. 77 (2006) 521528.

[40] Morin P., Britten M., Jiménez-Flores R., Pouliot Y., Microfiltration of buttermilk and washed cream buttermilk for concentration of milk fat globule membrane components, J. Dairy Sci. 90 (2007) 2132-2140.

[41] Munro S., Lipid rafts: Elusive or illusive, Cell 115 (2003) 377-388.

[42] Pan Y., Lee A., Wan J., Coventry M.J., Michalski W.P., Shiell B., Roginski H., Antiviral properties of milk proteins and peptides, Int. Dairy J. 16 (2006) 1252-1261.

[43] Purdy A., Case L., Duvall M., OverstromColeman M., Monnier N., Chervonsky A., Golovkina T., Unique resistance of $\mathrm{I} / \mathrm{LnJ}$ mice to a retrovirus is due to sustained interferon gamma-dependent production of virusneutralizing antibodies, J. Exp. Med. 197 (2003) 233-243. 
[44] Riccio P., The proteins of the milk fat globule membrane in the balance, Trends Food Sci. Technol. 15 (2004) 458-461.

[45] Roesch R.R., Corredig M., Production of buttermilk hydrolysates and their characterization, Milchwissenschaft 57 (2002) 376380.

[46] Rombaut R., Dejonckheere V., Dewettinck K., Microfiltration of butter serum upon casein micelle destabilization, J. Dairy Sci. 89 (2006) 1915-1925.

[47] Rombaut R., Dejonckheere V., Dewettinck K., Filtration of milk fat globule membrane fragments from acid buttermilk cheese whey, J. Dairy Sci. 90 (2007) 1662-1673.

[48] Rombaut R., Dewettinck K., Thermocalcic aggregation of milk fat globule membrane fragments from acid buttermilk cheese whey, J. Dairy Sci. 90 (2007) 2665-2674.

[49] Roos S., Jonsson H., A high-molecularmass cell-surface protein from Lactobacillus reuteri 1063 adheres to mucus components, Microbiology 148 (2002) 433-442.

[50] Sachdeva S., Buchheim W., Recovery of phospholipids from buttermilk using membrane processing, Kiel. Milchwirtsch. Forschungsber. 49 (1997) 47-68.

[51] Sára M., Conserved anchoring mechanisms between crystalline cell surface S-layer proteins and secondary cell wall polymers in gram-positive bacteria?, Trends Microbiol. 9 (2001) 47-49.

[52] Sára M., Sleytr U.B., S-layer proteins, J. Bacteriol. 182 (2000) 859-868.

[53] Saslowsky D.E., Lawrence J., Ren X.Y., Brown D.A., Henderson R.M., Edwardson J.M., Placental alkaline phosphatase is efficiently targeted to rafts in supported lipid bilayers, J. Biol. Chem. 277 (2002) 26966-26970.

[54] Schaer-Zammaretti P., Ubbink J., Imaging of lactic acid bacteria with AFM - elasticity and adhesion maps and their relationship to biological and structural data, Ultramicroscopy 97 (2003) 199-208.
[55] Scheffer L., Solomonov I., Weygand M.J., Kjaer K., Leiserowitz L., Addadi L., Structure of cholesterol/ceramide monolayer mixtures: Implications to the molecular organization of lipid rafts, Biophys. J. 88 (2005) 3381-3391.

[56] Sillanpaa J., Martinez B., Antikainen J., Toba T., Kalkkinen N., Tankka S., Lounatmaa K., Keranen J., Hook M., Westerlund-Wikstrom B., Pouwels P.H., Korhonen T.K., Characterization of the collagen-binding S-layer protein CbsA of Lactobacillus crispatus, J. Bacteriol. 182 (2000) 6440-6450.

[57] Sodini I., Morin P., Olabi A., Jiménez-Flores R., Compositional and functional properties of buttermilk: A comparison between sweet, sour, and whey buttermilk, J. Dairy Sci. 89 (2006) 525-536.

[58] Spitsberg V.L., Bovine milk fat globule membrane as a potential nutraceutical, J. Dairy Sci. 88 (2005) 2289-2294.

[59] Surel O., Famelart M.H., Ability of ceramic membranes to reject lipids of dairy products, Aust. J. Dairy Technol. 50 (1995) 36-40.

[60] Walstra P., Geurts T.J., Noomen A., Jellema A., van Boekel M.A.J.S., Colloidal particles of milk, in: Dairy technology: Principles of milk properties and processing, Marcel Dekker, New York, NY, 1999, pp. 727.

[61] Ward R.E., Watzke H.J., Jiménez-Flores R., German J.B., Bioguided processing: A paradigm change in food production, Food Technol. 58 (2004) 44-48.

[62] Welsch U., Schumacher U., Buchheim W., Schinko I., Jenness P., Patton S., Histochemical and biochemical observations on milk-fat-globule membranes from several mammalian-species, Acta Histochem. 40 (Suppl.) (1990) 59-64.

[63] Yuan C., Furlong J., Burgos P., Johnston L.J., The size of lipid rafts: An atomic force microscopy study of ganglioside GM1 domains in sphingomyelin/DOPC/cholesterol membranes, Biophys. J. 82 (2002) 2526-2535. 